\author{
Ałła Brzozowska \\ Uniwersytet Wrocławski \\ alla.brzozowska@gmail.com
}

\title{
Edycja pierwszej mowy Erazma Ciołka (1474-1522) wygłoszonej w Rzymie wobec papieża Aleksandra $\mathrm{VI}^{1}$
}

\section{Abstract \\ An Edition of The First Speech of Erasm Ciołek (1474-1522), Delivered in Rome before Pope Alexander VI}

This paper presents the first critical edition of the first political speech by an important representative of the Polish Renaissance, Erazm Ciołek. He came to the Holy See with a diplomatic mission from the Grand Duke of Lithuania, Alexander Jagiellon, and delivered his oration before Pope Alexander VI in March 1501. As a young diplomat of little experience, he faced a difficult task: under the pretext of paying the tribute of obedience to the Pope, which was the mission's official purpose, he was supposed to broach the subject of a religious union between the Lithuanian Orthodox Church and the papacy in order to deprive Moscow of the argument to instigate war. Despite his initial reluctance to accept Ciołek, the Pope much appreciated his oratorical talent.

It is likely that the speech was first printed the same year in Rome, because as a print it could have had a greater outreach and thus helped the delegate achieve his

1 Publikacja powstała dzięki środkom Narodowego Centrum Nauki przyznanym na podstawie decyzji numer DEC-2011/01/N/HS2/03885. Artykuł jest częścią pracy doktorskiej napisanej pod kierunkiem prof. T. Szostek i obronionej w 2014 roku. 
political objective. However, even though the oration was highly regarded by the addressee, it has never been thoroughly studied. It has only been mentioned in a few historical studies. No critical edition with a proper commentary that would enable a wider audience to understand the content of Ciołek's performance has ever appeared. This paper contains an edition of the Latin text of the speech based on its $16^{\text {th }}$ century edition. The critical apparatus also includes all variants of the manuscript. The Polish translation was also provided with appropriate philological and historical comments. What is more, the introduction discusses the structure of the speech, or the orator's thread of persuasion. Both the introduction and the commentary to the translation are based largely on historical sources.

Key words: edition, political oration, Early-modern Lithuanian diplomacy, Polish and Lithuanian Renaissance, Erazm Ciołek

Z całej spuścizny pisarskiej szesnastowiecznego biskupa płockiego i dyplomaty Erazma Ciołka do naszych dni przetrwały cztery mowy wygłoszone przed obliczem trzech kolejnych papieży: Aleksandra VI, Juliusza II i Leona X, oraz cesarza Maksymiliana, a także siedemnaście listów - okruch pokaźnej niegdyś korespondencji. Spuścizna ta była i jest niemal całkowicie pomijana w pracach poświęconych polskiemu renesansowi. Wprawdzie współcześni Ciołka cenili go jako zręcznego dyplomatę oraz dobrego mówcę i opinie ich są powtarzane przez większość badaczy, ale, niestety, nikt się nie zdobył na analizę krytyczno-literacką, dzięki której można by się przekonać, na czym ów kunszt oratorski Erazma polegał. Nie ma też współczesnej edycji jego mów ani też ich przekładu². Zasadne wydaje się zatem przybliżenie dzisiejszemu czytelnikowi i szerszemu gronu odbiorców, pierwszej mowy Erazma Ciołka. Zwłaszcza że mowa ta, debiut

2 Pierwsze tłumaczenie przedstawionej tu mowy na język polski powstało w XIX wieku: E. Ciołek, Mowa Erazma Ciołka, Przełożonego Wileńskiego, Najjaśniejszego Księcia Aleksandra W.K. litewskiego sekretarza i posła do Aleksandra VI Papieża $z$ oświadczeniem postuszeństwa wyprawionego, miana w Rzymie roku pańskiego 1501, we środę, dnia ostatniego marca z dołaczeniem odpowiedzi Jego Świętobliwości, „Czas. Dodatek miesięczny” 20 (1860), s. 176-185. 
oratorski młodego posła, jest bardzo interesująca. Postanowiłam nakreślić strukturę retoryczną mowy, a także załączyć edycję tekstu łacińskiego wraz z przekładem na język polski.

$\mathrm{Na}$ swoją pierwszą misję dyplomatyczną wyjechał Erazm Ciołek w 1501 roku, gdy jako młody, zaledwie dwudziestosiedmioletni ${ }^{3}$ sekretarz wielkiego księcia litewskiego Aleksandra Jagiellończyka i prepozyt katedry wileńskiej został wysłany do Rzymu ze spóźnioną obediencją do papieża Aleksandra VI ${ }^{4}$ I choć oficjalnym celem legacji było złożenie hołdu, to prawdziwy powód wysłania poselstwa stanowiła unia kościelna między papiestwem a Kościołem prawosławnym Wielkiego Księstwa Litewskiego, zawarta na podstawie uchwał soboru florenckiego, która miała zakończyć wieloletnią wojnę z Księstwem Moskiewskim, roszczącym sobie prawo do ziem litewskich zamieszkanych przez prawosławnych ${ }^{5}$.

Z Krakowa poselstwo wyruszyło 12 stycznia 1501 roku. Jechało najpierw do Wenecji, do której dotarło 14 lutego ${ }^{6}$. Po tygodniowym

3 Jeśli uznamy za autentyczne epitafium Ciołka zanotowane przez ks. Jakuba Brzeźnickiego, na podstawie którego przyjęło się podawać datę urodzenia. Por. K. Miaskowski, $Z$ biblioteki seminarium duchownego w Poznaniu, „Przegląd Kościelny” 3 (sierpień 1904), s. 132.

4 Aleksander Jagiellończyk został wybrany na wielkiego księcia litewskiego w 1492 roku, a więc w chwili wysłania poselstwa do papieża w celu złożenia obediencji panował już od dziewięciu lat. Ponadto papież Aleksander VI już wcześniej, w 1498 roku, pisał do księcia Aleksandra, wzywając go do przysłania posłów na zjazd dotyczący wyprawy chrześcijan przeciw Turkom, który odbył się w marcu 1499 roku. Zob. A. Theiner, Vetera monumenta Poloniae et Lithuaniae, Roma 1861, t. 2, s. 266-267.

5 L. Birkenmajer, Zapiski historyczne wśród starych almanachów Biblioteki Jagiellońskiej, „Kwartalnik Historyczny” 16 (1902), s. 448. Szczegółowo tę kwestię przedstawia również Henryk Folwarski w pracy Erazm Ciołek biskup i dyplomata, Warszawa 1935, s. 22-50.

6 „A di 14 fevrer. [...] Item, fo chiamati alcuni zenthilomeni nostri, ad andar contra uno orator dil ducha di Lithuania, fradello dil re di Hongaria, vien in questa terra, et poi anderá a Roma, dove è destinato". M. Sanuto, I Diarii, Venezia 1880, t. III, kol. 1432-1433; L. Birkenmajer, Zapiski historyczne..., s. 448. 
pobycie, 20 lutego, wyruszyło do Rzymu . Do Wiecznego Miasta Erazm Ciołek wjechał uroczyście 11 marca przez bramę Wirydarza w asyście orszaku złożonego z 12 mężczyzn i 12 chłopców ubranych w białe okrycia, a także $\mathrm{z}$ towarzyszącym mu u boku gubernatorem Francisco de Remolino (1462-1518) oraz domownikami kardynałów Giovanniego Battisty Orsiniego (ca 1450-1503) i Juana Lópeza z Walencji (ca 1455-1501). Na spotkanie zaś poselstwu litewskiemu wyszli domownicy papieża i wszystkich kardynałów ${ }^{8}$.

Wbrew ceremoniałowi papież Aleksander VI nie zezwolił Ciołkowi na wystąpienie z uroczystą mową obediencyjną na obowiązu-

7 Dnia 16 lutego poselstwo zostało uroczyście przyjęte w Signorii, gdzie Ciołek wygłosił mowę: „A di XVI fevrer. In colegio vene l'orator dil ducha di Lithuania, zovene et dotto, et di formosa effigie. Fo accompagnato da molti patricij, et, senato a presso il principe, presentato la letera ducal di credenza, la copia di la qual sara sccripta qui soto, expose latine andava a Roma, e di la querra fa il suo ducha con il ducha di Moscovia, suo suozero, et che li oratori di ditti rossi. Qualli sono qui, si havesseno dato qualche sinistra information, non era; si oferiva etc. Il principe li rispose bene. Et questo era alozato a San Bartolomio a l'hostaria di San Zorzi. A con lui uno nanin”. M. Sanuto, I Diarii..., kol. 1432-1433.

8 „Feria quinta, 11 dicti mensis Martis, intravit Urbem per portam Viridarii venerabilis D. Vitellius prepositus ecclesie Vilnensis, orator Illmi. Alexandri magni ducis Lithuanie, fratris germani regum Ungarie, Polonie et Bohemie ac cardinalis Cracoviensis; expectavit in domo sive vinea Alexandri Neronis, que fuit olim D. Falconis, adventum cardinalium familiarum et horam introitus; et in eadem domo fuit receptus per familias cardinalium Ursini et Capuani. Ascendit equum et fuit receptus ab aliis familiis omnium cardinalium et Pape; equitavit inter dispostum, qui etiam venit, a dextris, et gubernatorem, a sinistris, oratores Venetorum et Florentinorum etiam interfuerunt. Papa erat in illa domo nova Francisci Gabagnes, cubicularii secreti Pape, tamen intra gelosiam, ne cognosceretur. Hic orator habuit duodecim scutiferos, omnes in vestibus longis albis, subtus et desuper nigris et duodecim parvos pueros quorum minor erat $\mathrm{X}$ annorum, si recte memini, eodem modo vestitos, qui immediate ante eum et post me equitabant. Associatus fuit ad domum quondam D. Gregorii Polycarpi magistri registri bullarum sub Monte Jordano, in via Sanguinea sita, in qua est hospitatus". J. Burchardus, Diarium sive rerum urbanarum commentarii (1483-1506), t. 3 (1500-1506), Paris 1885, s. 120; por. K. Hartleb, Działalność kulturalna biskupa-dyplomaty Erazma Ciołka, Lwów 1929, s. 56. 
jącym w podobnej sytuacji konsystorzu publicznym ${ }^{9}$. Erazm Ciołek najwidoczniej rozumiał, że taka decyzja Ojca Świętego pomniejsza znaczenie poselstwa litewskiego, co niewątpliwie byłoby utrudnieniem na drodze do osiągnięcia założonych celów, gdyż po dwóch dniach od podjęcia takiej decyzji przez papieża zanotował w swoim almanachu: turbacio, a następnie, na kilka dni przed publicznym wystąpieniem: consolatus sum ${ }^{10}$.

Swoją mowę wygłosił Erazm Ciołek 31 marca 1501 roku na konsystorzu tajnym w obecności papieża i 19 kardynałów ${ }^{11}$. Struktura

9 „Feria quarta, 17 mensis Martii praedicti, SS. D. noster in secreto consistorio decrevit non facere publicum consistorium pro receptione oratoris magni ducis Lithuaniae, et male, quia conveniebat huiusmodi receptioni publicum consistorium. Fecit tamen hoc Papa, ne haberet responsionem oratori dandam diligentius studere". J. Burchardus, Diarium sive rerum urbanarum..., s. 121.

10 L. Birkenmajer, Zapiski historyczne..., s. 448. Papież podjął decyzję o nieprzyjęciu Ciołka na konsystorzu publicznym 17 marca. Notatka Erazma o zamieszaniu dotyczy okresu 20-26 marca. Natomiast „pocieszony” (consolatus) został 27. Być może na spotkaniu z kardynałem-protektorem Polski i Litwy zapewniono go o łaskawym nastawieniu papieża.

11 Zob. J. Burchardus, Diarium sive rerum urbanarum..., s. 122-123: „Feria quarta, ultima Martii, fuit consistorium secretum in quo Franciscus Remolinus, protonotarius apostolicus, gubernator Urbis, fuit prefectus in archiepiscopum ecclesie Surrentine, pastoris solatio destitute. Hora consistorii, venerabilis D. Erasmus Vitellius prepositus ecclesie Vilnensis, orator magni ducis Lithuanie Alexandri, cum familia sua, quorum, ut supra dixi, duodecim erant vestiti ut in introitu ad Urbem, associatus a familiis RRmorum. DD. cardinalium, Ursini et Capuani, venit ad palatium, ad cameras Rmi. D. Capuani, ubi expectavit fînem consistorii. Quo finito, gubernator et alii prelati venerunt ei obviam usque ad cameras Capuani, ubi ille expectabat, et induxerunt illum usque ad cameram paramenti Pape, ubi eo dimisso, ipsi intraverunt cameram in qua erat consistorium, et locaverunt se ad sinistram Pape; eorum fuerunt numéro septem. Vocatus deinde orator, et post omnes familia sua, et quidam alii amici sui, qui eum associaverant, orator accessit ad Papam, osculatus est pedem ejus et manus et receptus est ad osculum oris; genuflexit iterum et presentavit Pape litteras ducis predicti, que erant credentiales, patentes, sigillo subimpresso, quas Papa dedit D. Adriano, secretario suo. Orator retrocessit extra circulum consistorii in opposito Pape, ubi genuflexit, ante se habens illud scabellum quod introitum consistorii claudit; ego ad ejus sinistram fui genuflexus continue apud eum. D. Adrianus legit litteras predictas, ad sinistram Pape geneflexus; quibus 
mowy jest bardzo przejrzysta: składa się ze wstępu (exordium), podzielonego na trzy części opowiadania (narratio) oraz zakończenia

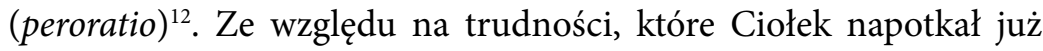
na początku swojej misji w Kurii Rzymskiej, szczególnie zadbał on o pozyskanie życzliwości odbiorcy we wstępie, który jest dość długi, zajmuje bowiem w strukturze całej mowy piątą jej część. Wypowiedź swą rozpoczyna passusem objaśniającym powód, dla którego wszyscy władcy chrześcijańscy winni uznać zwierzchność papieża i złożyć mu hołd, w ten sposób nawiązując jednocześnie do oficjalnego celu poselstwa wielkiego księcia litewskiego. Podaje tu mocny argument, który odnosi się do obowiązującej doktryny „wikariatu Chrystusowego” - „Tibi dabo claves regni caelorum, et quodcumque ligaveris super terram, erit ligatum in caelis" (Mt 16,19) - cytat z Pisma Świętego czyni autorytet papieża niepodważalnym, dodaje jednocześnie powagi całej wypowiedzi. Od początku przemówienia Ciołek zwraca swe słowa bezpośrednio do Ojca Świętego, ukazując adresata aktu komunikacji. W ten sposób nawiązuje $\mathrm{z}$ nim kontakt osobisty, próbuje zjednać jego sympatię. Przytoczona przez Ciołka geneza urzędu papieskiego uzasadnia także obecność poselstwa książęcego: przybywa ono bowiem w imieniu władcy chrześcijańskiego do osoby obdarzonej przez samego Stwórcę władzą najwyższą, namiestnika Boga na ziemi. Następnie przechodzi mówca do przedstawienia własnej osoby. Erazm Ciołek był wówczas młodym człowiekiem, nieznanym w Stolicy Apostolskiej, godność zaś posła, a zwłaszcza posła przyjeżdżającego z obediencją, była zazwyczaj powierzana albo przedstawicielom rodów magnackich o odpowiedniej pozycji społecznej i pełniących określoną funkcję państwową, albo ludziom doświadczonym i odpowiednio bardziej dojrzałym

lectis, orator ut supra genuflexus fecit orationem omnibus laudatam, cum optima pronuntiatione et aptitudine [...]".

12 Analiza mowy jest przedstawiona na podstawie pierwszego wydania pochodzącego prawdopodobnie z 1501 roku: E. Ciołek (Erasmus Vitellius), Alexandri magni ducis Lithuaniae secretarii et oratoris ad Alexandrum sextum pontificem maximum in prestita obedientia Romae habita oratio [Roma: Ioannes Besicken, 1501]. 
wiekiem oraz zasłużonym w służbie. Młody wiek posłańca książęcego nie mógł ujść uwagi słuchaczy. Na niekorzyść Ciołka działał także z pewnością brak szlacheckiego pochodzenia. Być może z tego powodu papież był początkowo nastawiony negatywnie i odmówił posłowi litewskiemu wystąpienia na konsystorzu publicznym, odbierając fakt wysłania niedoświadczonego młodego człowieka jako gest lekceważenia wobec Stolicy Apostolskiej. Należało więc z tego się wytłumaczyć i spróbować pozyskać początkowo niechętnego słuchacza. Wybrnął z tej kłopotliwej sytuacji Erazm Ciołek bardzo zręcznie. Obrał bowiem za wzór do naśladowania pierwszą mowę Cycerona, w której dwudziestosześcioletni, wówczas znany niewielu mówca bronił w sądzie Sekstusa Roscjusza z Amerii i w bardzo podobny sposób budował porozumienie $\mathrm{z}$ odbiorcą, uprzedzając zdziwienie, dlaczego właśnie on podjął się tego zadania ${ }^{13}$. Nawiązując zatem intertekstualną grę ze słynną mową Cycerona, uprzedza Ciołek pytania i ewentualne zarzuty słuchających, a jednocześnie zjednuje sobie ich przychylność, czyniąc własną osobę wiarygodną w ich oczach dzięki szczerej wypowiedzi:

Tametsi uero habuerit praesules dignissimos et plures ducatus primores, uiros equidem prudentes et militari balteo nobilissimos, quibus id peragendum digne committere potuisset aut saltem eorum aliquem mihi in collegam associare, hoc tamen repentinus bellorum insultus prohibuit, ubi inter magna et diuersa discrimina magnis etiam consiliis et diuersis militum experientiis indiget. Quamobrem ducalis celsitudo ad complenda uota sua me solitarium deputare uoluit.

To zatem nie brak doświadczonych i zasłużonych ludzi zmusił wielkiego księcia do wysłania młodego sekretarza do Ojca Świętego, lecz nader ciężka sytuacja polityczna - nagły atak zbrojny. Jest to zdanie istotne, gdyż wprowadza w nim Erazm podmiot wypowie-

13 Zob. Cicero, Pro S. Roscio Amerino, 1: „Credo ego vos, iudices, mirari quid sit quod, cum tot summi oratores hominesque nobilissimi sedeant, ego potissimum surrexerim, is qui neque aetate neque ingenio neque auctoritate sim cum his qui sedeant comparandus". 
dzi, czyli siebie, oraz osobę księcia Aleksandra, w którego imieniu występował na forum, przedmiot swojej wypowiedzi, a także rzeczywisty powód misji dyplomatycznej, który zostanie rozwinięty w dalszej części mowy i przedstawiony szczegółowo na audiencjach prywatnych u Ojca Świętego ${ }^{14}$. Następnie zwraca się do papieża oraz obecnej na konsystorzu szerszej publiczności - do zgromadzonych kardynałów - i, podkreślając ich zasługi oraz talenty wobec braku własnych, czyli wykorzystując tak charakterystyczną dla teorii wstępu formułę skromności (topos modestiae) ${ }^{15}$, prosi Boga o pomoc, a Ojca Świętego o łaskawość:

Et reuera nisi me tum magnanimi principis imperium, tum seruilis et humillima parendi necessitas hortarentur et cogerent, numquam tam grande et primum inter uulgus periculum subiissem, ubi se unum cunctis tacentibus praebeam audiendum [...]. Restat, ut periculum imminens et notam erroris ac ignorantiae tute euitare possem, diuinam opem et Tuam, qui Dei in terris uices geris, clementiam cum uenia imploro.

Powyższy zabieg ma na celu pozyskanie przychylności słuchaczy. Wywołuje u odbiorcy naturalną chęć sprzyjania człowiekowi, na którego złożono trudny do wypełnienia obowiązek.

Część egzordialna została ukształtowana zgodnie z zaleceniami retoryki: na początku jest wyeksponowany nadawca, adresat i przedmiot wypowiedzi. Posłużył się Ciołek także stosowną dla wstępu formułą skromności. Taka struktura pełni istotną rolę w akcie komunikacji - realizuje trzy główne funkcje wypowiedzi: docere, movere, delectare. Powoduje, że to, o czym mówi autor, jest przejrzyste, łatwe

14 Por. J. Burchardus, Diarium sive rerum urbanarum..., s. 123; H. Folwarski, Erazm Ciołek..., s. 31; L. Birkenmajer, Zapiski historyczne..., s. 449.

15 Por. Quintilianus, Institutio Oratoria, IV 1, 8: „Sed ut praecipua in hoc dicentis auctoritas, si omnis in subeundo negotio suspicio sordium aut odiorum aut ambitionis afuerit, ita quaedam in his quoque commendatio tacita, si nos infirmos, inparatos, inpares agentium contra ingeniis dixerimus [...]". 
w odbiorze. W ten sposób zadbał autor szczególnie o odpowiednie przygotowanie umysłów słuchaczy do dalszej części mowy ${ }^{16}$.

Następnie przechodzi Ciołek do narratio, którą przecinają liczne wtrącenia (argumenta), wzmacniające wiarygodność wypowiedzi. Rozpoczyna poseł opowiadanie od opisu kraju, z którego przybywa i który reprezentuje. Podkreśla, że jest to kraj chrześcijański, którego ludność, poznawszy prawdę o Bogu, dobrowolnie przeszła na wiarę Chrystusową i trwa w niej niezachwianie. Dowodzi tego, wskazując na liczne kościoły i siedziby biskupów, które w krótkim czasie po przyjęciu chrześcijaństwa wybudowali Litwini na swojej ziemi. Stwierdzenie to pełni istotną funkcję w wypowiedzi, gdyż nie tylko przedstawia stanowisko strony litewskiej, lecz, nawiązując intertekstualną grę (budząc skojarzenia ze znanymi tekstami opisującymi Księstwo jako ostoję pogaństwa), Ciołek odrzuca wrogą argumentację. Wyraźnie polemizuje tu z panującą na Zachodzie, w tym również w Stolicy Apostolskiej, opinią na temat Wielkiego Księstwa Litewskiego opartą na relacjach Hieronima z Pragi spisanych w dziełach Eneasza Sylwiusza Piccolominiego, a następnie powtórzonych przez Hartmanna Schedla, opinią umacnianą również przez innych, przede wszystkim protektorów i stronników zakonu krzyżackiego ${ }^{17}$. Poparta papieskim, a także akademickim autorytetem opinia utrudniała starania polityczne wielkiego księcia litewskiego na arenie międzynarodowej. Należało więc przy każdej sposobności z istniejącym stereotypem walczyć.

16 Por. Quintilianus, Institutio Oratoria, IV 1, 5: „Causa principii nulla alia est quam ut auditorem quo sit nobis in ceteris partibus accommodatior praeparemus. Id fieri tribus maxime rebus inter auctores plurimos constat, si beniuolum attentum docilem fecerimus, non quia ista non per totam actionem sint custodienda, sed quia initiis praecipue necessaria, per quae in animum iudicis ut procedere ultra possimus admittimur".

17 A. Brzozowska, Wizerunek Polski i Litwy w mowach politycznych biskupa płockiego Erazma Ciołka (1474-1522), „Studia Classica et Neolatina” 12 (2014), s. 81-96. 
Nawiązując bezpośredni kontakt z Ojcem Świętym i skupiając na sobie jego uwagę, zapowiada Ciołek kolejny przedmiot swojej wypowiedzi oraz przechodzi do epidejktycznego opisu ziemi litewskiej. Zgodnie z zaleceniami Kwintyliana można podzielić ten opis według następujących cech godnych pochwały: ze względu na rodzaj i położenie (ex positione et specie); ze względu na to, jaką przynosi korzyść (ex utilitate) oraz ze względu na mieszkańców (ex civibus) ${ }^{18}$. Polemizując ze znanymi na Zachodzie tekstami opisującymi ziemię litewską, stosuje się Ciołek do wskazówek Arystotelesa, aby według potrzeby z wad czynić zalety ${ }^{19}$, i to, co wcześniej było przedstawiane negatywnie, opiewa w laudacji. Całe opowiadanie poświęcone opisowi ojczystego kraju jest przecięte dwoma zwrotami do odbiorcy. Pierwszy zwrot został wprowadzony po zapewnieniu, że mieszkańcy Litwy wyznają wiarę chrześcijańską, zawiera on też zapowiedź następujących elementów opisu (partitio): ziemi i ludności. Drugi zwrot spaja wyżej wymienione dwa elementy i pobudza uwagę odbiorcy. Zabieg ten był szczególnie zalecany w traktatach retorycznych w sytuacji, gdy narratio była długa: zwroty więc przygotowywały odbiorcę i zapobiegały pojawieniu się uczucia niechęci czy znudzenia ${ }^{20}$.

Po ukazaniu rzeczy godnych pochwały (quod est honestum, laudandum), przechodzi Ciołek do drugiej części narratio - opisu wrogów Wielkiego Księstwa Litewskiego, czyli tego, co jest godne potępienia (quod est turpe, vituperandum). Wrogami zaś nieustannie zagrażającymi bezpieczeństwu Litwy byli z jednej strony Księstwo Moskiewskie, z drugiej zaś Tatarzy, z którymi owo księstwo się sprzymierzało ${ }^{21}$. Aby przybliżyć słuchaczom przedmiot swojej mowy, zaczyna poseł ten passus od porównania (argumentum ex similitudine), a właściwie zrównania Tatarów z tak dobrze znanymi w świecie

18 Quintilianus, Institutio Oratoria, III 7, 26-27.

19 Zob. Aristoteles, Rhetorica, 1367b.

20 Zob. H. Lausberg, Retoryka literacka. Podstawy wiedzy o literaturze, tłum.

A. Gorzkowski, Bydgoszcz 2002, s. 188-189.

21 F. Papée, Aleksander Jagiellończyk, Kraków 2006, s. 35-45. 
chrześcijańskim Turkami. Następnie przedstawia szczegółową charakterystykę dwóch chanów tatarskich: jacy są, jakie tereny zamieszkują, czym się od siebie różnią, jakie są ich obyczaje oraz jakie zagrożenie niosą dla Księstwa Litewskiego. Opis Tatarów i ich najazdów jest bardzo plastyczny, dlatego nie wymaga dodatkowych zabiegów pobudzających uwagę odbiorcy. Na końcu tej charakterystyki padają słowa oskarżenia pod adresem innych władców chrześcijańskich, którzy nigdy żadną pomocą nie wsparli nękanego przez barbarzyńców kraju wspólnej wiary. W kolejnych słowach nawiązuje Ciołek do pozostałego bez odpowiedzi listu papieża z 1498 roku, wzywającego wielkiego księcia Aleksandra do przysłania posłów na sobór poświęcony wyprawie przeciw Turkom ${ }^{22}$. Nie tłumaczy się jednak $\mathrm{z}$ braku obecności posłów litewskich, ale skupia się na pochwale papieskiej decyzji. Odwraca w ten sposób uwagę od uchybienia książęcego i, kierując uczucia słuchaczy w odpowiednią stronę, pozyskuje ich życzliwość. Podaje również argument podnoszący rolę księcia na arenie międzynarodowej - zamiast słów konkretne działania podjęte w celu ułatwienia realizacji wyprawy, czyli podpisane zawieszenie broni $z$ jednym $\mathrm{z}$ chanów tatarskich, oraz przyczynę przerwania tych czynności: bezpodstawną i niesprawiedliwą wojnę, przez podstęp i wiarołomstwo wszczętą przez księcia moskiewskiego.

Wieńczy tę część opowiadania deklaracja złożona w imieniu księcia Aleksandra o przystąpieniu do wspólnych działań, pod warunkiem zakończenia wojny z Moskwą. Jest to bardzo ważny passus, gdyż dzięki niemu do odbiorcy został wysłany komunikat, w jakiej sytuacji wielki książę będzie mógł zrealizować plany papieskie. Erazm Ciołek przygotowywał w ten sposób grunt do osiągnięcia celu swojej misji dyplomatycznej, gdyż po przedstawieniu problemu (czyli walki Litwy z bliskimi Turcji ze względu na wyznawaną wiarę i położenie geograficzne Tatarami), zapewnieniu o chęci wielkiego księcia przystąpienia do przygotowywanej przez papieża krucjaty, a także ukazaniu jedynej przeszkody stojącej Litwie na drodze do

22 Zob. A. Theiner, Vetera monumenta Poloniae et Lithuaniae..., s. 267. 
niej (to znaczy wojny z Moskwą), Erazm Ciołek wskazał na sposób usunięcia tej przeszkody, a mianowicie zakończenie konfliktu litewsko-moskiewskiego - tym samym skłaniał umysł odbiorcy do sposobu rozwiązania tego problemu, w tym wypadku utworzenia unii kościelnej między papiestwem a Kościołem prawosławnym Litwy.

W kolejnej części mowy przechodzi Erazm Ciołek do pochwały księcia Aleksandra i całego rodu Jagiellonów. Zabieg często stosowany w mowach okolicznościowych, tutaj był elementem wręcz niezbędnym. W Kurii Rzymskiej ukazywano Wielkie Księstwo Litewskie oraz rodzinę panującą $\mathrm{w}$ bardzo niekorzystnym świetle. Należało z jednej strony odeprzeć zarzuty przeciwników, z drugiej - przedstawić własne racje, a podkreślając zalety rodu panującego, umocnić pozycję polityczną księstwa. Ciołek chwali zatem królewską i książęcą krew obecnego władcy, jego przodka - mężnego Witolda, poległego w walce z Turkami Władysława Warneńczyka, Kazimierza Jagiellończyka - króla polskiego, jego synów: przedwcześnie zmarłego Kazimierza, który po śmierci wsławił się licznymi cudami, kardynała Fryderyka, prymasa Polski, obecnego króla polskiego Jana Olbrachta i wreszcie samego Aleksandra, zrównanego przez Ciołka z Aleksandrem Macedońskim. Poprzez pochwałę polemizuje z obiegową opinią: u każdego bowiem z władców rodu Jagiellonów wskazuje zalety tam, gdzie na arenie międzynarodowej zarzucano im wady. Opis kończy Ciołek bezpośrednim zwrotem do Ojca Świętego, w którym, tłumacząc spóźnienie poselstwa odległością i niespokojnymi czasami, składa papieżowi hołd posłuszeństwa w imieniu księcia Aleksandra i wszystkich mieszkańców Litwy. Zakończona $\mathrm{w}$ ten sposób narratio zwracała uwagę odbiorcy: przypominała mu o oficjalnym celu poselstwa litewskiego, a tym samym umożliwiała przejście (transitus) do końcowej części mowy.

Zgodnie z zasadami opisanymi w traktatach retorycznych, w zakończeniu (peroratio) przywołał Ciołek na powrót zaprezentowane w exordium osoby aktu komunikacyjnego: nadawcę i odbiorcę wypowiedzi. W formie bezpośredniego laudacyjnego zwrotu do papieża, przypomniawszy mu sprawowany przezeń niegdyś urząd protektora Polski i Litwy, zachęcał go do stałej opieki nad tymi krajami. 
Prezentowana oracja jest przykładem mowy popisowej z elementami mowy politycznej, gdzie przeważają elementy opisowe. Mowy bowiem należące do genus demonstrativum koncentrują się na wykonaniu, pokazie sztuki oratorskiej, który jest ukierunkowany na ukazanie piękna lub szpetoty danej materii sprawy pochwalonej bądź potępionej przez mówcę ${ }^{23}$. Równocześnie Ciołek zasygnalizował oczekiwania wobec odbiorcy, tak że owe opisy w całej strukturze mowy pełnią funkcję dowodów, uprawomocniają przedstawione oczekiwania, mające charakter i cel polityczny.

Jak już wspomniano, konstrukcja mowy jest bardzo przejrzysta - autor przedstawił spójny wywód, przygotowując grunt do osiągnięcia celu swojej misji dyplomatycznej.

Mowa wywarła pozytywne wrażenie na audytorium ${ }^{24}$. Papież, początkowo nieprzychylny Ciołkowi i jego misji, po wysłuchaniu przemówienia chwalił go szczerze i osobiście uhonorował godnością

23 H. Lausberg, Retoryka literacka..., s. 135.

24 Zob. J. Burchardus, Diarium sive rerum urbanarum..., s. 122: „Feria quarta, ultima Martii, fuit consistorium secretum in quo Franciscus Remolinus, protonotarius apostolicus, gubernator Urbis, fuit prefectus in archiepiscopum ecclesie Surrentine, pastoris solatio destitute. Hora consistorii, venerabilis D. Erasmus Vitellius prepositus ecclesie Vilnensis, orator magni ducis Lithuanie Alexandri, cum familia sua, quorum, ut supra dixi, duodecim erant vestiti ut in introitu ad Urbem, associatus a familiis RRmorum. DD. cardinalium, Ursini et Capuani, venit ad palatium, ad cameras Rmi. D. Capuani, ubi expectavit fînem consistorii. Quo finito, gubernator et alii prelati venerunt ei obviam usque ad cameras Capuani, ubi ille expectabat, et induxerunt illum usque ad cameram paramenti Pape, ubi eo dimisso, ipsi intraverunt cameram in qua erat consistorium, et locaverunt se ad sinistram Pape; eorum fuerunt numéro septem. Vocatus deinde orator, et post omnes familia sua, et quidam alii amici sui, qui eum associaverant, orator accessit ad Papam, osculatus est pedem ejus et manus et receptus est ad osculum oris; genuflexit iterum et presentavit Pape litteras ducis predicti, que erant credentiales, patentes, sigillo subimpresso, quas Papa dedit D. Adriano, secretario suo. Orator retrocessit extra circulum consistorii in opposito Pape, ubi genuflexit, ante se habens illud scabellum quod introitum consistorii claudit; ego ad ejus sinistram fui genuflexus continue apud eum. D. Adrianus legit litteras predictas, ad sinistram Pape geneflexus; quibus lectis, orator ut supra genuflexus fecit orationem omnibus laudatam, cum optima pronuntiatione et aptitudine [...]". 
protonotariusza ${ }^{25}$, wysłał również do wielkiego księcia Aleksandra list poświęcony niemal całkowicie pochwale młodego oratora ${ }^{26}$ oraz korespondencję świadczącą, że sprawy poruszone przez Erazma nie pozostały bez odzewu ${ }^{27}$. Wprawdzie nie osiągnął Ciołek w swojej misji dyplomatycznej całkowitego sukcesu, jakim byłoby utworzenie unii między Kościołem rzymskokatolickim a Kościołem prawosławnym Litwy, to jednak drzwi zostały otwarte ${ }^{28}$. Ponadto pozyskał Erazm Ciołek liczne beneficja zarówno dla Wielkiego Księstwa Litewskiego, jak i dla siebie samego ${ }^{29}$. W grudniu 1501 roku poselstwo opuściło Rzym i 28 stycznia 1502 roku powróciło do Krakowa ${ }^{30}$.

Za podstawę niniejszej edycji pierwszej mowy Erazma Ciołka przyjęto druk znajdujący się w Rzymie w Biblioteca Casanatense pod sygnaturą RARI 781. Druk jest bardzo rzadki, dostępny jeszcze jedynie w zbiorach Biblioteki Watykańskiej pod sygnaturą Inc.IV.54(34), a także w Bibliotece Jagiellońskiej (sygn. Cim 5359). W książce nie

25 Zob. Ibidem: „[...] cui Papa respondit, prout voluit, et responsionem hujusmodi conclusit in laudem oratoris, subjungens quod proptera faceret eum ex nunc protonotarium apostolicum. Orator accessit ad Papam et post eum omnis familia sua, que osculata est pedem Pape, oratore ad dexteram Pape stante. Cui postquam familia pedem Pape osculata est, deposui vestem superiorem, quam, licet nobis esset debita, dedi uni ex familiaribus suis, sperans nos meliorem recompensam recepturos; paraveram prius pro eo rocchettum, cappam et capellum protonotariatus, quibus Papa, omnibus cardinalibus consistorialiter consedentibus, oratorem successive induit et eum protonotarium fecit et creavit. Surrexit orator, deposuit capellum et cappam, accepit mantellum et capucium sibi ad hoc prius ordinatum, et cum licentia Pape venit ad domum suam, associatus a familia Rmi. D. cardinalis Capuani”. Inaczej trochę zapisał relację z tego wydarzenia sekretarz Erazma Ciołka (albo sam posel) na końcu mowy.

26 Zob. A. Theiner, Vetera monumenta Poloniae et Lituaniae..., s. 288.

27 Ibidem, s. 280-297.

28 Na 13 kwietnia papież wyznaczył dla poselstwa litewskiego audiencję, na której debatowano o wierze. Zob. L. Birkenmajer, Zapiski historyczne..., s. 449. Następnie, 26 kwietnia, wysłał list do biskupa wileńskiego, nakazując dokładne zbadanie sprawy. ASV, Misc. Arm. XXXII, t. 21, f. 44-46. Por. A. Theiner, Vetera monumenta Poloniae et Lithuaniae..., s. 280-282.

29 ASV, Misc. Arm. XXXII, t. 21, f. 44-90.

30 L. Birkenmajer, Zapiski historyczne..., s. 449. 
ma zaznaczonego ani miejsca, ani roku wydania. Badacze podają, że prawdopodobnie wydrukowano ją w Rzymie, w 1501 roku, w typografii Jana Besickena ${ }^{31}$. Rękopis tej mowy zachował się w Archiwum Biblioteki Watykańskiej, w kodeksie o sygnaturze Misc. Arm. XXXII, t. 21, ff. 39v-42r, a następnie został opublikowany przez Augusta Theinera w Vetera monumenta Poloniae et Lithuaniae (s. 277-279). Jakkolwiek dla niniejszego wydania rękopis nie stanowił podstawy, to jednak wszelkie różnice zachodzące między tekstem starodruku a rękopisu uwzględniono $\mathrm{w}$ aparacie krytycznym, zamieszczonym w przypisach do tekstu łacińskiego.

W transkrypcji tekstu łacińskiego starano się jak najwierniej zachować pisownię oryginalną. Dla wygody odbiorcy jednak, a także $\mathrm{z}$ uwagi na niekonsekwencje w zapisie wydania szesnastowiecznego wprowadzono pewne zasady ujednolicające i porządkujące tekst:

- zmodernizowano pisownię dużych i małych liter;

- wprowadzono współczesne zasady interpunkcji;

- pozostawiono jednolity zapis głosek $\boldsymbol{u}$ i $\boldsymbol{v}$ jako „u” małą literą $\mathrm{i}$ „V” dużą (uiuit; Vrbs);

- rozwiązano bez zaznaczania wszystkie skróty i ligatury, np. cōmitteret - committeret; armoru - armorum; \& - et ; $\underline{p}$ - per; q-quod; $q 3$ - que etc.;

- uporządkowano zapis litery $\boldsymbol{e}$ oraz dyftongów ae i oe zgodnie z przyjętymi normami przede wszystkim w Słowniku łacińsko-polskim pod redakcją Mariana Plezi (Warszawa 1959-1979), np. celum, coelum - caelum; que - quae;

- usunięto niepotrzebne podwojenia liter, np. littus - litus; Litthuania - Lithuania; hiisce - hisce;

- zmieniono $\boldsymbol{c h}$ na $\boldsymbol{h}$ w takich wyrazach, jak: michi - mihi; nichil - nihil;

- zgodnie z współczesnymi normami usunięto lub wprowadzono literę $\boldsymbol{h}$ w pisowni takich wyrazów, jak: habunda - abunda;

- pozostawiono bez zmian skróty takie, jak: nil, firmasse.

31 Zob. F. Barberi, Tipografi Romani del Cinquecento, Firenze 1983, s. 167. 
Wszystkie typowe błędy zecerskie poprawiono bez zaznaczania tego w tekście. Tekst łaciński opatrzono niezbędnym aparatem krytycznym, znajdującym się w przypisach dolnych. Paralelne tłumaczenie na język polski wzbogacono stosownym, umożliwiającym bądź ułatwiającym odbiorcy zrozumienie tekstu komentarzem filologiczno-historycznym.

Erasmi Vitellii C. praepositi Vilnensis, illustrissimi domini Alexandri magni ducis Lithuaniae secretarii et oratoris ad Alexandrum Sextum Pontificem Maximum in praestita oboedientia Romae habita oratio.

Oryginał: ASV, Misc. Arm. XXXII, t. 21, f. 39v-42r.

Kopia: brak danych.

Druk: Romae, s. 1. et a.; A. Theiner, Vetera monumenta Poloniae et Lituaniae, Romae 1861, s. 277-279.

Saluator noster Iesus Christus post multa ac uaria diuinae ordinationis suae instituta unum designare uoluit, cui ianuam regni sui caelestis integerrima libertate gubernandam committeret, Tuae uidelicet Celsitudinis, Pontifex Sancte, praedecessorem illum primarium Petrum Piscatorem, ut quod praeceptis salutaribus ad perpetuam beatitudinem consequendam sanctierat in terris, hoc per unius potestatem et omnium credentium irrefragrabilem oboedientiam firmaret in caelis, sacratissimo attestante eloquio, cum dixerat: Tibi dabo claues regni caelorum et quodcumque ligaueris super terram, erit ligatum in caelis et reliqua. Quae etiam ad te dicta nemo est, qui ambigat, cum rite et legitime Sedem hanc Sanctam conscenderis, diligentique prouidentia fultus merito locum Petri possides.

Itaque, Ianitor Excellentissime, ut aperias, pulsare necesse est, et omne seruitutis obsequium a christianis principibus tibi, supremo christianae religionis gubernatori, totiusque gratiae et clementiae conseruatori, pulsa quauis temeritate, iuste praestari debet, quemadmodum in dies deuotissime exhibetur. Quo monarchia christiana creuit florentissime, dum id, quod necessario facere debuit, sincero et beniuolenti effectu non neglexit. 
Itidem nunc illustrissimus dominus Alexander, magnus Lithuaniae princeps, per me instituit explendum singulari ad hanc Sanctam Sedem permotus deuotione et affectu. Tametsi uero habuerit praesules dignissimos et plures ducatus primores, uiros equidem prudentes et militari balteo nobilissimos, quibus id peragendum digne committere potuisset aut saltem eorum aliquem mihi in collegam associare, hoc tamen repentinus bellorum insultus prohibuit, ubi inter magna et diuersa discrimina magnis etiam consiliis et diuersis militum experientiis indiget. Quamobrem ducalis celsitudo ad complenda uota sua me solitarium deputare uoluit. Et reuera nisi me tum magnanimi principis imperium, tum seruilis et humillima paren $\mathrm{di}^{1}$ necessitas hortarentur et cogerent, numquam tam grande et primum inter uulgus periculum subiissem, ubi se unum cunctis tacentibus praebeam audiendum, praesertim coram Tuae Sanctitatis diuino quodam numine et aspectu tamquam celeberrimo reuerendissimorum cardinalium ordine, quae mentem humanam, quantumcumque fortem et audentem, tamquam micantia sidera deterrent et fulgore prudentissimo consternunt fiatque (si bene didici ${ }^{2}$ ), ut tam sacrae maiestatis nouitate attonita paueat et titubet. Considero enim hoc in loco non nisi uiros graues, consilio doctos et aetate maturos simile officium absoluisse, quorum uestigia dum attentius intueor, perpeditum mihi dicendi ornatum, cum desit facundia, adem[p]tamque oratoris dignitatem remota experientia animaduerto, illuc enim continuus armorum strepitus litterarum rudimenta non admittit. Restat, ut periculum imminens et notam erroris ac ignorantiae tute euitare possem, diuinam opem et tuam, qui Dei in terris uices geris, clementiam cum uenia imploro.

Amplissimus ducatus Lithuaniae ab annis quattuordecim supra centum, relictis gentilitatis erroribus, christianam religionem professus $^{3}$ est, quam non miraculis conuertentis, sed sponte cognita

1 ms. parcendi

2 ms. si benedicti

3 ms. profectus 
ueritate ad ducis ipsorum hortamenta deuotissime susceperunt et hucusque inconcussam constanter obseruant, ac in dies pro eiusdem catholicae religionis honore et augmento cooperari non desistunt. Testantur id plurima Dei templa munificentissime ornata et sedes episcopales bene dotatae et honestissime prouisae. Tantum illi sub hoc breuissimo tempore ad fidem sanctam allecti in sincera caritate et magna diuini cultus dilectione profecerunt. Et ut terra ipsa per loci et gentis descriptionem Tuae Sanctitati paulisper cognita sit, liceat pace tua deliberata coram proferre.

Est quidem Lithuania longe lateque patens prouincia inter orientem et septentrionem sita, noningentorum miliarium spatio in circuitu contenta Sarmatiam Europae continuans, inclito Regno Poloniae uicina, maris Cimbrici in Baltico litus habet, Boristene et aliis fluuiis utilissimis alluitur, qui alueorum magnitudine proprio impetu feruntur in mare, non mediocre cum maximis lacubus afferentes commodum. Terram habet fertilissimam, quae tritici omniumque frugum copiam germinat. Melle abundat, quo aqua cocto loco uini utitur tantumdem saluberrimo. Aurum et argentum plurimum semper accipit pro cera, quam de melle extrahit sufficientissime, et illam sola ad longinquas regiones transmittit. Diuersa etiam commercia mari illi Germanico opportune suggerit, pro quibus sal, uinum, species et pannos egregios facillime conquirit. Pelles omnium generum cariores toti fere orbi communicat. Ceruos, bisontes, onagros, usui humano conuenientes, in magna multitudine gignit. Relinquo cetera, quae soli bonitas pro utilitate patriae illius et decore profert gratis$\operatorname{sima}^{4}$. Vtcunque enim multa enumerare uellem, plura me praetermisisse comperiam. Habet praeterea uirorum sobolem audentissimam, tam corporum eminenti robore, quam etiam animorum connata quadam industria pulchre a natura prouisam. Nullius unquam praeter ducis sui paruerunt imperio, qui - dum alios etiam duces ditissimos sibi habeat subiectos - solus magni ducis titulum per excellentiam ferre potest. Linguam propriam obseruant, uerum quia Rutheni me-

4 ms. gratissime 
dium fere ducatum incolunt, illorum loquela, dum gracilis et facilior sit, utuntur communius. Exteros homines de uirtute ipsorum singulari quadam gratia et affectu prosequuntur. Contra rectum et honestum nihil unquam moliri possunt, sola simplici ueritate bene docti et fide illaesa munitissimi.

Sed, proh dolor, Turci religioni crucis sanctae hostes acerrimi, quemadmodum per annos plurimos, et praesertim hisce temporibus, regna, principatus et alia christianorum dominia uastauerunt et depopularunt, nonnulla etiam loca suae potestati et imperio miserabiliter subiugantes. Sic quoque Tartari christiano etiam nomini infestissimi, eidem sectae machometicae concatenati, neque minus potentes, ipsorum tirannidem et crudelitatem atrocissimam contra ducatum illum diuerterunt ${ }^{5}$. Habet namque ducatus iste duos Scytharum caesares potentissimos, lateri suo contiguos: unum trans Tanaim fortiorem, qui centum milibus equitum in statione campestri ponere potest, et hic remotior est, paludi Meotide applicans; alterum circa Boristenem Caphae finitimum, qui etsi primo debilior sit, propinquior tamen, quo facilius continuas incursiones in finibus ducatus facere solet. Et quia Caphae uicinus est, quam Turcus possidet, dum maioribus uiribus pugnare contendit, etiam Turci Caphensis auxilia conquirit, cum quo sortem aequalem in diuidendis spoliis per modum pacti obseruat. Ab his ducatus Lithuaniae per potentes et creberrimas incursiones assidue impetitur, et iacturam accipit. Super quorum insultus, quamuis ducalis celsitudo diligenter tempore quolibet animaduertat ${ }^{6}$ custodiam et militum praesidia ${ }^{7}$ in finibus adhibendo, raro tamen cum eisdem proelium committi potest: nam genus est hominum fugacissimum, arcu, sagitta et framea armatorum, quippe qui luporum more clandestinis incursionibus dediti numquam in acie persistunt. Et cum dux ipse, pro debito tutandae reipublicae, potentem aduersus eosdem hostes profectionem parat,

5 ms. divertantur

6 ms. animo advertat

ms. praesidio 
et iam interdum castra sua ipsorum residentiae propinquius admouerat, illico ad campestria et paludinosa latibula remotius aufugiunt. Tantum enim equorum celeritate et sua quadam patientia in perferendis laboribus praeualent, ut quod nostri per biduum cito satis transitu ire possunt, hoc illi dietim celerrime transuolant, neque eis aestus aut algoris niuiumque ${ }^{8}$ asperitas difficultatem praebent, sola gramina quantumcumque grossa equis eorum sufficiunt, quae hiemis tempore, dum niue profundissime tecta sint, ungula quaerendo excutiunt et tanquam recentibus pabulantur. Illis equi fessi, laboribus consumpti, dum iam uiribus destituuntur, esca sunt placidissima et sanguis in modum pulmenti cibus est nobilior. Sola aqua etiam paludinosa et utcumque turbida sitim restinguunt, quibus si contenti facillime per illos campos latissimos, ubi nil praeter caelum et terram conspicatur, ueniunt depopulatum et redeunt. Milites uero ducales, quia tantum defectum pro sua et equorum condicione sustinere nequeunt, si eos in oris ducatus intrantes aut exeuntes profligare neglexerint, amplius insequi non possunt, itineris longitudine et alimentorum penuria prohibente.

Dum igitur eadem Tartarorum gens ferocissima, quotannis immo et mense quolibet, sine ulla intermissione ducatum hunc damnificet, continuum et paene indelebile cum eis bellum gerit, nullo unquam subsidio de uicinis christianorum dominiis habito. Nuper uero dum illustrissimus magnus dux ex litteris Tuae Sanctitatis intellexerat omnes christianorum principes ad unanimem actionem contra atrocissimos Turcos praeparati, gratulabatur plurimum, quod semotis discordiis intestinis publicae utilitati consuleretur attentius, quae prudentissima prouidentia tua pro pastoralis dignitatis officio instituere curauit ad illud tam sanctum propositum totam uniuersitatem christianam paternis hortamentis inuitando. Quandoquidem cupiat desideranter gregem dominicum a luporum rapacitate protegere, ut illa hostilitas potentissima, quae per tot tempora diuisis et priuatis defensionibus uinci non poterat, sic coadunatis uiribus Christo

${ }^{8}$ ms. nimiumque 
annuente domino superaretur commodius et de propriis etiam sedibus pulsa facilius aboleri possit, rediretque ad perpetuam tui sacri nominis memoriam pax noua in terris. Quibus motus dux ipse conceperat sub eodem tempore pertinenter uni Tartarorom caesari Caphae finitimo bellum totis uiribus inferre, durante eadem christianorum actione, ne Turco in subsidium uenire potuisset. Et pro liberiori actione sua celerique effectu treugas pacis cum altero Tanaita pepigerat, iamque belli primitias huic anno transacto dedicarat, nisi eum ducis Moskouii ${ }^{9}$ fraus et fracta fides per bellum temerarium et iniustum a proposito retraxisset. Vult tamen aduersus Tartaros instituta constanter prosequi, dummodo ceptam cum Moskouitis ${ }^{10}$ actionem iustitia sancta auxiliante feliciter terminauerit.

Ortum autem tanti principis dignissimum paucis explicabo. Habet enim sublimitatem generis clarissimam, de domibus regum et alta principum familia honestissime deductam, cuius auus eiusdem ducatus habens gubernacula reiecto errore primus fidem Christi suscepit, illico nutu quodam diuino in regem Poloniae electus. Vitoldus uero frater suus, sacro etiam baptismate tunc insignitus, in administranda republica doctissimus, seueritatem pietate moderans, ducatum mira aequitate et prouidentia regebat, ut suis semper nedum praeesse, sed prodesse magis curauerit. Hic primus illis leges condidit et plurimas aedes sacras pro amplianda fide construxit, in defendendo ab hostibus dominio strenuus fuerat et inuictissimus propugnator, unde per laudem et famam omnium uulgarissimam magnum nomen tempestate sua promeruerat. Quae dum caesar Sigismundus perfectius didicisset (prouinciae etiam amplitudine motus), sibi coronam per oratores proprios duxerat transmittendam et, ut regia fulsisset maiestate, indulsit. Voluit enim iustissimus ille princeps et uerus Augustus uirtutem condigno praemio decorare cunctis in exemplum. Sed antequam oratores sui uenientes iter ceptum perfecissent, mors Vitoldum, celerius quam debuerat, oppres-

9 ms. Moszkovii

10 ms. Moszkovitis 
sit. Moriebatur demum rex Poloniae germanus, cui succedebant filii, Vladislaus in regnum, qui postea et Hungaris praefuit. Hic pro sancta religione contra gentem Machometicam uiriliter pugnans una cum Iuliano cardinali gloriosissime occubuit, multis antea triumphis honorifice de hoste reportatis. Kazimirus tandem frater suus, qui post patris obitum ducatum Lithuaniae per electionem obtinuerat, iterum post fratris necem ad regnum accipitur. Hic per multos annos utrumque dominium felicissime gubernans prolem reliquit ingenuam, e quibus maiorem, dum uixerat, regno Bohemiae tranquille et sine quouis tumultu praefecit, et hic quidem ob praestantissimas animi sui dotes Hungaris etiam hodie imperat. Alterum uero sui nominis Kazimirum, adolescentem profecto doctrina et excellenti ingenio, ac uitae probitate ornatissimum, mors inuida, maiora parantem, surripuit. Qui in urbe ducatus primaria sepultus plurimis citra annos uiginti claret miraculis, uota cuiuslibet suis apud Deum meritis commendans, ut neminem spe frustrari permittat, quae aliquando simul congesta huic Sanctae Sedi declarabuntur cumulatius. Eodem ordine connumerandus uenit aetate iunior illustrissimus princeps et reuerendissimus dominus Fredericus diuina miseratione et tuo munere presbyter cardinalis, episcopus et archipraesul regni illius dignissimus, qui tanquam columna nitidissima totius Sarmatiae ordinem ecclesiasticum illustrat et in statu honesto diligenti regimine suo prudenter et mature conseruat. Quid de filiabus uenustissimis, Germaniae ducibus propter loci uicinitatem honestissimo matrimonio iunctis, sic optimus ille parens pro singulari uoluptate sua talem prolis exaltationem uidere poposcit et meruit. Quo uita functo, tertiogenitus filius, Iohannes Albertus, nunc rex Poloniae serenissimus, magna rerum experientia praeeminens paternam sedem pacifice conscendit. Magniducatus tunc etiam primores mox Alexandrum quartogenitum in dominum et patrem patriae sub electionis ordine unanimiter susceperunt. Iste omni uirtute decoratus, gratissimum se nedum suis, sed exteris etiam omnibus hucusque exhibuit, quippe qui auo religionis integritate, et patruo fidei constantia et defensione, ac genitori gratia et connata benignitate similis censeatur. Animi uero magnitudine et insigni liberalitatis ornamento Magno illi 
Alexandro Macedoni merito aequari potest. Alia missa, nunc facio, quae siderum cursus per eum ad christiani nominis gloriam futura praenuntiat.

Itaque, Beatissime Pater, excellentissimus iste princeps feruenti et sincero affectu pro debito uenerationis officio, te unicum Ihesu Christi vicarium Romanae Ecclesiae et totius christianae religionis pontificem maximum recognoscit, cui firmam fidem et ueram oboedientiam praestat, ac perpetuo pollicetur. Quae etsi serius, quam debuerat, compleuerit, loci tamen distantia et temporum inquietudo tarditatem excusant. Hoc ipsum faciunt uniuersi ecclesiastici et saeculares Lithuaniae praelati, totumque illud popolosissimum dominium, qui omnes uno ore passim te uerum et legitimum Petri successorem profitentur et se eiusdem gratiae humillime commendant.

Sed ne longiori sermone pias aures defatigare potius quam oblectare uidear, sciamque excellentissimam prudentiam tuam, Pontifex Beatissime, rerum magistra experientia omnia haec nosse plenius, quippe qui cancellariatus uices huius Sanctae Sedis longissimis temporibus feliciter gubernaras, ubi domum hanc candidae aquilae florentissimam potenter tuebaris, constans igitur sis et effice, ut quod tunc pro decore huius clarissimae familiae impetrabas, hodie solita benignitate de nauiculae plenitudine effundas et motu proprio largiaris, omnia namque potes. Dixi.

Ad haec Summus Pontifex abunda satis uti uoluit responsione, laudans et extollens mirifice auum, patruum, neque minus genitorem et totam fere huius excellentissimi principis generationem, uirtute etiam ipsius commendata, praedicans palam amplissimum ducatum Lithuaniae inclitaque regna Hungariae et Poloniae uera antemuralia et totius christianitatis contra gentem Machometicam propugnacula semper ualidissima extitisse, quaslibet demum orationis habitae sententias singillatim repetendo, egitque ducali celsitudini immortales gratias suo et reuerendissimorum cardinalium nomine pro tanta ad Sanctam Sedem Apostolicam reuerentia et affectu. Obtulit se tandem paratissimum ad omnia, quae in eius et dominii sui 
ornamentum cederent. Oratorem uero ex singulari gratia prothonotariatus dignitate ibidem manibus propriis decorauit.

\section{Mowa Erazma Ciołka, prepozyta wileńskiego, przesławnego Pana Aleksandra, Wielkiego Księcia Litwy, sekretarza i posła do Papieża Aleksandra VI, wygłoszona w Rzymie na okoliczność złożenia uroczystego hołdu posłuszeństwa}

Zbawiciel nasz, Jezus Chrystus, po ustanowieniu licznych i różnych praw swego boskiego porządku, jednego zechciał wyznaczyć, któremu powierzył, aby niepodzielną władzą strzegł bram jego królestwa niebieskiego, mianowicie owego znakomitego poprzednika Twojej Wysokości, Ojcze Święty, Piotra Rybaka umocował, by to, co zbawiennymi nakazami ustanowił na ziemi do uzyskania wiecznej szczęśliwości, przez władzę jedynego i nienaruszalną przysięgę posłuszeństwa wszystkich wierzących utrwalił na niebie, najświętszym słowem poświadczając, gdy powiedział: Tobie dam klucze królestwa niebieskiego i cokolwiek zwiażesz na ziemi, będzie zwiazane $w$ nie$b i e^{11}$, i tak dalej. I nie ma nikogo, kto by wątpił, że te słowa także do Ciebie [są skierowane], wszak zgodnie z prawem i obyczajem wstąpiłeś na Stolicę Apostolską, a wspierany przez troskliwą Opatrzność, zasłużenie miejsce św. Piotra zajmujesz.

Przeto, Odźwierny Najwyższy, abyś otworzył, należy kołatać12 i chrześcijańscy władcy Tobie, najwyższemu przewodnikowi religii chrześcijańskiej i stróżowi wszelkiej łaski i łagodności, odrzuciwszy nierozwagę, słusznie powinni złożyć hołd posłuszeństwa, jak też na co dzień pobożnie je okazywać. Dlatego monarchia chrześcijańska

\footnotetext{
11 Mt 16,19.

12 Mt 7,7.
} 
rozrosła się wspaniale, gdyż tego, co z konieczności należało uczynić, ze szczerej i życzliwej woli nie zaniedbała.

Tego właśnie teraz Najjaśniejszy Pan Aleksander, wielki książę litewski, powodowany szczególnym dla tej Stolicy Apostolskiej oddaniem i przywiązaniem, postanowił przeze mnie dopełnić. Wprawdzie posiadał nader godnych kapłanów i licznych dostojników w księstwie, mężów niewątpliwie roztropnych i wyróżnionych pasem rycerskim, którym mógł odpowiednio powierzyć wykonanie tej [misji], albo przynajmniej któregoś z nich dodać mi jako towarzysza, jednak przeszkodził temu niespodziewany wybuch wojny ${ }^{1}$, gdy wśród wielkich i rozmaitych niebezpieczeństw także wielkich rad i rozmaitego doświadczenia żołnierskiego potrzeba. Dlatego też Jego Książęca Wysokość do załatwienia swoich spraw mnie samego zechciał wyprawić ${ }^{2}$ I doprawdy, gdyby nie dodawały mi otuchy i nie nagliły z jednej strony rozkaz wielkodusznego księcia, z drugiej zaś służebny i pokorny obowiązek posłuszeństwa, nigdy bym nie podjął się publicznie tak wielkiego wyzwania: siebie jako jedynego mówcę przed ogółem milczących wystawić, szczególnie przed boskim majestatem i obliczem Twojej Świątobliwości, jak też przed tak licznym gronem czcigodnych kardynałów. Wszystko to umysł ludzki, jakkolwiek mocny i odważny, niby migocące gwiazdy odstrasza, poraża blaskiem mądrości, i wydawałoby się (jeśli prawidłowo rozpoznałem), że [umysł ten] oszołomiony nowością świętej

1 W maju 1500 roku Iwan III zerwał pokój z 1494 roku i przy wsparciu Tatarów krymskich oraz hospodara Mołdawii uderzył na Wielkie Księstwo Litewskie. Zob. K. Pułaski, Stosunki z Mendli-Girejem, chanem Tatarów Perekopskich (1469-1515), w: Stosunki Polski z Tatarszczyzna od połowy XV wieku, t. I, Kraków-Warszawa 1881, s. 82; H. Łowmiański, Polityka Jagiellonów, Poznań 1999, s. 420-421; F. Papée, Aleksander Jagiellończyk..., s. 73.

2 W rzeczywistości Erazm Ciołek miał towarzysza, sekretarza wielkoksiążęcego Iwana Sapiehę, z którym mieli przedstawiać papieżowi projekt unii Kościoła prawosławnego Wielkiego Księstwa Litewskiego z Kościołem katolickim. Jednakże temat ten miał być poruszony na audiencjach prywatnych. Oficjalnym celem misji było złożenie hołdu papieżowi. Por. ASV, Misc. Arm. XXXII, t. 21, f. 47v-50. 
powagi drży i się chwieje ${ }^{3}$. Albowiem zdaję sobie sprawę, że w tym miejscu jedynie mężowie poważni, biegli w radzie i dojrzali wiekiem wypełniali podobny obowiązek; gdy w ich ślady bacznie się wpatruję, dostrzegam nadmierną ozdobność mojej wymowy spowodowaną niedostatkiem talentu, i - jako ujmę godności poselskiej - brak doświadczenia; tam bowiem, skąd przybywam, ciągły szczęk broni nie pozwala na elementarne nawet nauki ${ }^{4}$. Pozostaje [mi] - aby bezpiecznie uniknąć zagrażającego niebezpieczeństwa oraz hańby błędu i niewiedzy - pokornie błagać o pomoc Bożą i o Twoją, który Boga na ziemi zastępujesz, łagodność.

Rozległe Księstwo Litewskie, porzuciwszy błędy pogaństwa, ponad sto czternaście lat temu przyjęło wiarę chrześcijańską, na którą [mieszkańcy] nie cudami zostali nawróceni, lecz, dobrowolnie poznawszy prawdę, na zachęty swojego księcia żarliwie odpowiedzieli i po dziś dzień nienaruszoną [wiarę] wytrwale zachowują, i co dzień nie ustają we współdziałaniu ku czci i na rzecz szerzenia religii katolickiej ${ }^{5}$. Dowodzą tego liczne szczodrze ozdobione świątynie oraz dobrze uposażone i dostojnie obsadzone siedziby biskupów. Jedynie oni, od tak niedawna przyjęci do świętej wiary, podążają w szczerej miłości i z wielkim przywiązaniem do kultu Bożego. I by ziemia ta poprzez opisanie położenia i ludności stała się cokolwiek znana Twojej Świątobliwości, niech wolno mi będzie po uzyskaniu twojej zgody osobiście [ją] przedstawić.

3 Młody, zaledwie dwudziestosiedmioletni Erazm Ciołek, pozyskując przychylność odbiorcy, buduje początek swojej pierwszej publicznie wygłoszonej mowy na wzór pierwszej mowy Cycerona, którą w wieku dwudziestu sześciu lat obronił Sekstusa Roscjusza z Amerii. Zob. M.T. Cicero, Pro S. Roscio Amerino, 1.

4 W istocie Erazm Ciołek był absolwentem Akademii Krakowskiej, na której w 1491 roku uzyskał tytuł magister artium. Por. Statuta nec non liber promotionum philosophorum ordinis in Universitate Studiorum Jagiellonica ab anno 1402 ad annum 1849, ed. J. Muczkowski, Kraków 1849, s. 103.

5 Na Zachodzie Litwa była przedstawiana jako kraj, w którym wciąż było żywe pogaństwo. Wizerunek ten nie sprzyjał międzynarodowej polityce tego państwa, a zatem przy każdej sposobności należało podkreślać przynależność Litwy do świata chrześcijańskiego. Por. A. Brzozowska, Wizerunek Polski i Litwy..., s. 81-96. 
Otóż jest Litwa księstwem bardzo rozległym, położonym między wschodem a północą, rozciągającym się na przestrzeni dziewięciuset mil; będąc przedłużeniem Sarmacji Europejskiej, sąsiaduje ze sławnym Królestwem Polskim, posiada wybrzeże Morza Cymbryjskiego ${ }^{6}$ na Bałtyku; obmywa ją Dniepr i inne bardzo pożyteczne rzeki, które własnym przepływem ogrom fal niosą ku morzu, wraz z wielkimi jeziorami niemały pożytek przynosząc. Ma [Litwa] niezwykle żyzną ziemię, co rodzi moc pszenicy i wszystkich owoców; obfituje w miód, który po ugotowaniu z wodą spożywa się zamiast wina jako [napój] przynoszący zdrowie. Złoto i srebro dostaje za wosk, którego pod dostatkiem z miodu otrzymuje i tylko ona do odległych zakątków go przesyła. Również inne różnorodne towary pomyślnie dostarcza nad owo Germańskie Morze ${ }^{7}$, za które sól, wino, przyprawy i sukna wyborne z łatwością pozyskuje. Skóry najrzadsze wszystkich rodzajów całemu niemal światu daje. Jelenie, żubry, łosie, tak ludziom przydatne, w wielkiej obfitości rodzi ${ }^{8}$. Pomijam inne [plony], które bogata ta ziemia dla pożytku i chwały ojczyzny wydaje. Jakkolwiek wiele chciałbym wymienić, musiałbym stwierdzić, że jeszcze więcej

6 Część Morza Północnego omywająca Półwysep Jutlandzki (dawniej nazywany Chersonezem Cymbryjskim) od zachodniej strony. Zob. Novum lexicon geographicum [...], wyd. Ph. Ferrarius, wydanie poprawione: M.A. Baudrand, t. I, Venezia: Homobono Bettanino, 1738, s. 157, 363. Ciołek jednak, mówiąc o Morzu Cymbryjskim, ma na myśli Morze Bałtyckie.

7 Dawna nazwa Morza Północnego. Zob. ibidem, s. 363; G. Fournier, Geographica orbis notitia, per litora maris, et ripas fluviorum, pars I, lib. IV, cap. 1, Frankfurt 1668, s. 107-108.

8 Opis Litwy u Ciołka jest laudacją. Podczas gdy w tym samym okresie powszechna opinia funkcjonująca na Zachodzie o kraju litewskim była raczej dla Litwinów niekorzystna. Litwę przedstawiano jako kraj dziki i biedny, a ludność tam zamieszkującą jako nieucywilizowaną. Por. Pius II P.M., Asiae Europaeque descriptio, Köln 1531, s. 358-365; I.Ph. Forestus, Supplementum Chronicarum, Venezia 1535, f. 15v-16r, 358rv. Pierwsze wydanie, zawierające bardzo dużo nieprawdziwych informacji o Polsce i Litwie, ukazało się w 1483 roku i było często wznawiane, m.in. w 1484, 1486, 1490, 1491 i inne. Pierwsze poprawki zostały wprowadzone przez autora dopiero w 1503 roku; H. Schedel, Liber Chronicarum cum figuris et imaginibus, Nürnberg 1493, f. 287v-288v. 
pominąłem. Posiada ponadto bardzo odważne potomstwo mężów, zarówno wielką krzepą cielesną, jak też pewnym wrodzonym sprytem umysłu pięknie przez naturę obdarzonych. Są posłuszni jedynie rozkazom swojego księcia, który, podczas gdy ma innych bogatych książąt sobie poddanych, jako jedyny w pełnym tego słowa znaczeniu może nosić tytuł wielkiego księcia. Język własny zachowują, ale że jednak Rusini połowę niemal księstwa zamieszkują, ich mowy, gdyż jest delikatna i łatwiejsza, powszechnie używają. Cudzoziemców dla jedynej [tej] ich zalety traktują z uprzejmością i życzliwością. Przeciw temu, co słuszne i dobre, nigdy niczego nie potrafią uknuć dobrze pouczeni jedynie zwykłą prawdą i w niezłomną wiarę uzbrojeni.

Lecz o biada! Turcy, najbardziej zawzięci wrogowie wiary Świętego Krzyża, przez długie lata, a szczególnie w tych właśnie czasach, spustoszyli i wyludnili królestwa, księstwa i inne państwa chrześcijańskie, niektóre kraje także, na nieszczęście, podporządkowując swojej władzy i rozkazom 9 . Podobnie Tatarzy, równie nieprzyjaźni imieniu Chrystusa, złączeni z tą samą sektą mahometańską, nie mniej potężni [od Turków], tyranię swoją i najdziksze okrucieństwo przeciw wspomnianemu księstwu zwrócili. Ma bowiem to księstwo blisko swoich granic dwóch przemożnych chanów scytyjskich: jednego za Donem, mocniejszego, który sto tysięcy jeźdźców w obozie polnym wystawić może, i jest on bardziej oddalony, stoi obozem nad Morzem Azowskim ${ }^{10}$; drugiego nad Dnieprem, sąsiadującego z Kaf$\mathrm{fą}^{11}$, który, choć słabszy od pierwszego, bliżej jednak się znajduje ${ }^{12}$, przez co bez trudu nieprzerwanie najeżdża rubieże księstwa. A że

9 W momencie wygłaszania mowy Turcja prowadziła ekspansję również na terenach krajów chrześcijańskich. Od chwili zajęcia Konstantynopola w 1453 roku kolejne chrześcijańskie państwa przechodziły bezpośrednio pod władzę Osmanów (Serbia, Bośnia) albo też stawały się wasalami Turcji (Mołdawia).

${ }_{10}$ Orda Zawołżańska (Wielka).

11 Dzisiejsze miasto Teodozja znajdujące się na Półwyspie Krymskim.

12 Tatarzy krymscy (perekopscy). 
jest sąsiadem Kaffy, która należy do Turka ${ }^{13}$, gdy większymi siłami zamierza walczyć, uzyskuje pomoc tychże kaffijskich Turków, z którymi na mocy układu ma równe udziały w dzieleniu łupów. Oni stale nękają księstwo litewskie poważnymi i bardzo częstymi najazdami, oraz szkody przynoszą. I choć na ich napady Jego Książęca Wysokość cały czas zwraca szczególną uwagę, wystawiając na pograniczu wartę i oddziały żołnierzy, rzadko jednak może stoczyć z nimi [bezpośrednią] bitwę: jest to bowiem rodzaj ludzi nader skorych do ucieczki, uzbrojonych w łuk, strzałę i włócznię, zwłaszcza że - podobni wilkom - podczas podstępnych najazdów nigdy nie trwają złączeni w szyku. I kiedy tylko sam książę dla należnej obrony państwa znaczną wyprawę przeciw tymże wrogom urządza, i niekiedy już obóz swój bliżej do ich siedziby przysunie, [tamci] natychmiast dalej do polnych i bagnistych kryjówek uciekają. Tak dużą bowiem mają przewagę dzięki szybkości koni i własnej wytrzymałości, że [odległość], jaką nasi przez okres dwóch dni w szybkim dość marszu przebyć mogą, oni w dzień prędko pokonują, i ani upały, ani mrozy czy zbytnia gwałtowność [pogody] nie sprawiają im trudności. Ich koniom wystarcza jedynie gruba, sucha trawa, którą, żeby znaleźć, konie w porze zimowej kopytem odgrzebują, gdyż jest przykryta głębokim śniegiem, i tak niby świeżą się żywią. Kiedy konie ich są zmęczone, $\mathrm{z}$ trudu wyczerpane i pozbawione już sił, stają się wdzięcznym dla nich pokarmem, a krew - jak gdyby łakomy kąsek - wyborną potrawą. Zwykłą też wodą bagienną i mętną gaszą pragnienie, dzięki czemu, gdy są zaspokojeni, z łatwością dla rabunku przemierzają rozległe pola, gdzie nic prócz nieba i ziemi nie widać, i wracają ${ }^{14}$.

13 Dawna kolonia Genueńczyków, Kaffa na Krymie, została zaanektowana przez Turków w 1475 roku.

14 Poseł królów węgierskiego, Władysława, oraz polskiego, Jana Olbrachta, Mikołaj z Rozenberga, kawaler jerozolimski, wysłany w maju 1498 roku na sejm cesarstwa do Freiburga przedstawił cesarzowi obszerny opis Scytów, w tym Tatarów, ich pochodzenia, różnych plemion, obyczajów, a także dziejów. Relacja ta znajduje się w sporządzonym przez Erazma Ciołka zapewne na potrzeby misji dyplomatycznych Liber legationum. Zob. AGAD, LL3, f. 101r-107r. 
Żołnierze zaś książęcy, ponieważ z uwagi na naturalne ograniczenia własne i koni nie są w stanie tak długo wytrzymać niedostatku, jeśli nie zdążyli pokonać [wrogów] kursujących na obrzeżach księstwa, powstrzymywani długością wyprawy i brakiem żywności dalej ich ścigać nie mogą.

Podczas gdy więc owo dzikie plemię tatarskie każdego roku, a nawet każdego miesiąca, bez przerwy to księstwo pustoszy, ciągłą i prawie ustawiczną prowadzi [ono] z nimi wojnę, nie uzyskawszy nigdy żadnego wsparcia ze strony sąsiadujących państw chrześcijańskich. Ale kiedy niedawno Najjaśniejszy Wielki Książę z listu Twojej Świątobliwości się dowiedział ${ }^{15}$, że wszyscy władcy chrześcijańscy przygotowują się do jednomyślnego działania przeciw strasznym Turkom, cieszył się niezmiernie, że, porzuciwszy wewnętrzne spory, baczniej się zastanawiają nad pożytkiem publicznym, który Twoja rozważna przezorność za obowiązek godności pasterskiej postarała się ustanowić, ojcowskimi zachętami zapraszając do tego tak świętego przedsięwzięcia całe powszechne chrześcijaństwo. Gdyż gorąco pragnie [Twoja Świątobliwość] strzec trzody pańskiej przed drapieżnością wilków, aby ową potężną armię wroga, której przez tyle czasu nie zdołano przezwyciężyć rozproszonymi i prowadzonymi we własnym zakresie próbami obrony, tak zjednoczonymi siłami, przy sprzyjającym Chrystusie Panu, zręczniej pokonano, a wypędzoną z własnych także siedzib łatwiej można było unicestwić, i aby ku wiecznej Twego imienia pamięci nowy pokój na ziemi powrócił. Poruszony tym książę sam postanowił w tym właśnie czasie wszystkimi siłami zaatakować odpowiednio jednego chana tatarskiego sąsiadującego z Kaffą, aby nie mógł on przyjść Turkom z pomocą w trakcie wyprawy chrześcijan. I już dla swobodniejszego działania i szybszego końca wypłacił [złoto] za rozejm z drugim [chanem stojącym] nad

15 List papieża wzywający księcia Aleksandra do wysłania posłów w sprawie powszechnej wyprawy przeciw Turkom. Zob. ASV, Misc. Arm. XXXII, t. 21, f. 107; A. Theiner, Vetera monumenta..., s. 266-267. 
Donem $^{16}$, i już w zeszłym roku rozpocząłby pierwsze kroki wojenne, gdyby go nie odwiodły od [tego] zamiaru podstęp i wiarołomstwo księcia moskiewskiego ${ }^{17}$, [który wszczął] zuchwale niesprawiedliwą wojnę $^{18}$. Chce jednak [wielki książę] to, co postanowił przeciwko Tatarom, konsekwentnie wykonać, jak tylko przy pomocy świętej sprawiedliwości położy szczęśliwie kres rozpoczętym z Moskalami działaniom [wojennym].

O dostojnym zaś pochodzeniu tak wielkiego księcia pokrótce opowiem. Odznacza się on bowiem znakomitością rodu, wywodzącego się zacnie z domów królewskich i wysokiej rodziny książęcej ${ }^{19}$. Dziadek jego, gdy trzymał stery tegoż księstwa, porzuciwszy błędy [pogaństwa], jako pierwszy przyjął wiarę Chrystusa ${ }^{20}$. Wnet z woli Bożej wybrany został na króla Polski ${ }^{21}$. Jego zaś brat Witold, świętym chrztem również naznaczony, wielce doświadczony w kierowaniu państwem, miarkując surowość pobożnością, rządził księstwem

16 Dnia 11 stycznia 1501 roku Polska i Litwa sprzymierzyły się z chanem Wielkiej Ordy Szejch Ahmedem przeciwko Wielkiemu Księstwu Moskiewskiemu i Tatarom krymskim. Zob. L. Podhorodecki, Chanat krymski i jego stosunki z Polskq w XV-XVIII w. Warszawa 1987, s. 35.

17 Iwan III Srogi (1440-1505) wielki książę moskiewski w latach 1462-1505.

18 Wiosną 1500 roku książę moskiewski Iwan III ponownie zaatakował ziemie Wielkiego Księstwa Litewskiego: na południowym wschodzie i w okolicy Briańska i Dorohobuża. W tym samym czasie czambuły Tatarów Krymskich najechały południowe krańce Litwy i Polski.

19 Na Zachodzie szerzono plotkę, że synowie Jagiełły, których miał w sędziwym już wieku, nie byli jego dziećmi, tylko jakiegoś rycerza litewskiego, a zatem nie mieli prawa do sukcesji po ojcu. Zob. A.S. Piccolomini, De viris illustribus, Stuttgart 1842, s. 48. Dlatego na arenie międzynarodowej należało podkreślać wysokie i prawowite pochodzenie Jagiellonów.

20 Jagiełło (ok. 1352-1434), syn wielkiego księcia litewskiego Olgierda i Julianny Twerskiej, po śmierci ojca w roku 1377 wstąpił na tron Wielkiego Księstwa Litewskiego. W 1385 roku - na mocy unii w Krewie - w zamian za rękę króla Polski Jadwigi i objęcie tronu polskiego Jagiełło zobowiązał się przyjąć chrzest i chrystianizować również Litwę, co nastąpiło rok później.

${ }_{21}$ Dnia 15 lutego 1386 roku Jagiełło przyjął w Krakowie chrzest i nowe imię Władysław, a 18 lutego w katedrze na Wawelu zawarł związek małżeński z Jadwigą. 
z godną podziwu sprawiedliwością i przezornością, dbał, aby nie tylko stać na czele swoich [poddanych], lecz bardziej być im pomocnym $^{22}$. On jako pierwszy ustanowił [Litwinom] prawa i wybudował liczne świątynie dla szerzenia wiary, był energiczny i niezwyciężony w obronie państwa przed nieprzyjaciółmi: $\mathrm{z}$ tej to przyczyny zdobył wielkie imię za swoich czasów dzięki uznaniu wszystkich i powszechnej sławie. Gdy o tym dokładniej dowiedział się cesarz Zygmunt $^{23}$ (będąc pod wrażeniem także wielkości kraju), zamówił koronę, aby ją przez własnych posłów mu przesłać, i pozwolił, by zajaśniał królewskim majestatem ${ }^{24}$. Chciał bowiem ów najsprawiedliwszy władca i prawdziwy August stosowną nagrodą cnotę ozdobić, by stanowiła wzór dla wszystkich. Lecz zanim posłowie jego dojechali do celu podróży, pokonała Witolda śmierć szybciej niż

22 Witold (ok. 1354-1430), syn Kiejstuta i Biruty, brat stryjeczny Władysława Jagiełły, w 1401 roku został wielkim księciem litewskim. Dnia 21 października 1383 roku Witold przyjął chrzest w rąk wielkiego mistrza krzyżackiego. Zob. Skarbiec diplomatów papiezkich, cesarskich, królewskich, ksiązęcych: uchwał narodowych, postanowień różnych władz i urzędów posługujacych do krytycznego wyjaśnienia dziejów Litwy, Rusi litewskiéj i ościennych im krajów, zebrał i w treści opisał I. Daniłowicz, t. I, wyd. J. Sidorowicz, Wilno 1860, s. 248-249.

23 Zygmunt Luksemburski (1368-1437), syn Karola IV Luksemburskiego i Elżbiety Pomorskiej, trzeci i ostatni cesarz z dynastii luksemburskiej. W 1378 roku został elektorem brandenburskim, w 1387 - królem węgierskim, w 1410 roku został wybrany na króla rzymskiego, a od 1419 roku był królem Czech. W 1433 roku został koronowany na Świętego Cesarza Rzymskiego.

24 Na zjeździe w Łucku w 1429 roku, na który przyjechało wielu królów i książąt chrześcijańskich, trzej chanowie tatarscy, a także posłowie innych władców, król rzymski i węgierski Zygmunt Luksemburski wystąpił z projektem koronacji Witolda. Witold naradził się w tej sprawie z królem polskim Władysławem Jagiełło i otrzymał od niego przyzwolenie, a nawet zachętę. Jednakże rada królewska wyrażała sprzeciw wobec tego pomysłu. Po zakończeniu zjazdu posłów króla rzymskiego Zygmunta wiozących koronę dla Witolda zatrzymano w Polsce i zmuszono do powrotu. Ponadto Polacy oskarżyli Witolda wobec papieża i innych władców chrześcijańskich o dumne zamiary zdobycia korony dla siebie ze szkodą dla królestwa polskiego. Zob. ibidem, s. 100-110. Por. J. Długosz, Annales seu Cronicae incliti Regni Poloniae, ks. 11, 1413-1430, ed. J. Wyrozumski et al., Warszawa 2000, s. 249-292. 
powinna ${ }^{25}$. Umarł wreszcie spokrewniony [z nim] król Polski ${ }^{26}$, po którym objęli tron synowie. Władysław w Królestwie Polskim, który później również na Węgrzech rządzi2²7. On to, gdy mężnie walczył za religię świętą przeciwko muzułmanom, odniósłszy przedtem pokaźne nad wrogiem zwycięstwa ${ }^{28}$, razem $\mathrm{z}$ kardynałem Julianem chwalebnie poleg ${ }^{29}$. Brat wreszcie jego, Kazimierz, który po śmierci ojca objął przez elekcję księstwo litewskie, po stracie brata ponownie [został] przyjęty do królestwa ${ }^{30}$. Przez wiele lat $\mathrm{z}$ sukcesem kierując obydwoma państwami, pozostawił [po sobie] szlachetnych potomków, z których najstarszego, jeszcze za swojego życia, spokojnie i bez żadnych zamieszek postawił na czele Królestwa Czeskiego i on właśnie ze względu na zacne przymioty swego ducha dziś także Węgrami rządzi ${ }^{31}$. Drugiego zaś [syna] noszącego jego imię, Kazimierza,

25 Ibidem.

26 Władysław II Jagiełło zmarł 1 czerwca 1434 roku w Gródku.

27 Władysław III Warneńczyk (1424-1444), syn Władysława II Jagiełły i jego czwartej żony, Zofii Holszańskiej, po śmierci ojca w 1434 roku został wybrany królem Polski, a sześć lat później, w 1440 roku, został królem Czech i Węgier.

${ }^{28}$ W 1443 roku król Władysław stanął na czele zbrojnej wyprawy przeciw Turkom, która zakończyła się zwycięstwem. W 1444 roku w Segedynie podpisał z Turkami dziesięcioletni pokój, ale ulegając namowom papieża i jego legata, Juliana Cesariniego, zerwał układy i poprowadził wojsko przeciwko Turkom. Niestety, poniósł dotkliwą klęskę w bitwie pod Warną, w której został prawdopodobnie zabity. Ponadto w bitwie zginął, również prawdopodobnie, papieski legat, kardynał Juliano Cesarini. Zob. Jan Długosz, Annales seu Cronicae incliti Regni Poloniae, ks. 1112, 1431-1444, red. J. Wyrozumski et al., Warszawa 2001, s. 282-294, 298-308, 311-326.

29 Ciała króla Władysława ani ciała kardynała Cesariniego nigdy nie znaleziono. Zarówno w tamtym okresie, jak i obecnie istnieje wiele hipotez opisujących ich losy. Zob. http://www.treccani.it/enciclopedia/giuliano-cesarini_\%28Dizionario-Biografico\%29/ [dostęp: 1.10.2016].

30 Kazimierz IV Andrzej Jagiellończyk (1427-1492) najmłodszy syn króla polskiego Władysława II Jagiełły i jego ostatniej żony, Zofii Holszańskiej. W 1440 roku został wybrany na wielkiego księcia litewskiego, a w 1447 roku, trzy lata po śmierci brata, Władysława III Warneńczyka, objął również tron w Polsce.

31 Władysław II Jagiellończyk (1456-1516), najstarszy syn króla polskiego Kazimierza IV Jagiellończyka i Elżbiety Rakuszanki. W 1471 roku został wybrany na króla Czech, a w 1490 na króla Węgier i Chorwacji. 
młodzieńca wyróżniającego się prawdziwie uczonością i wybitnymi wrodzonymi zdolnościami, a także prawością życia, gotowego do [podjęcia] większych wyzwań, zawistna śmierć odebrała ${ }^{32}$. Pochowany w stołecznym mieście księstwa ${ }^{33}$ od dwudziestu przeszło lat licznymi cudami słynie, swoimi zasługami polecając przed Bogiem prośby wszystkich, by nie pozwolić nikomu pozostać ze zwodniczą nadzieją. Kiedyś [cuda] te razem z żywotem obszerniej Stolicy Apostolskiej zostaną przedstawione ${ }^{34}$. W dalszej kolejności wymienić należy młodszego wiekiem najjaśniejszego księcia i przewielebnego pana Fryderyka, z Bożej łaski, a z Twojego dobrodziejstwa kardynała prezbitera, biskupa i czcigodnego arcybiskupa tego królestwa, który jak najjaśniejsza kolumna całej Sarmacji stan duchowny uświetnia i pilnymi rządami swoimi w dostojnym położeniu roztropnie i dojrzale zachowuje ${ }^{35}$. Cóż [rzec] o pełnych wdzięku córkach, z uwagi na sąsiedztwo złączonych więzami małżeństwa z książętami niemieckimi $^{36}$ ? Tak najlepszy ten ojciec, dla osobistej swojej przyjemności,

32 Kazimierz Jagiellończyk (1458-1484), syn króla polskiego Kazimierza IV Jagiellończyka i Elżbiety Rakuszanki, polski królewicz. W 1481 roku został namiestnikiem Królestwa Polskiego. W 1602 roku został ogłoszony świętym Kościoła rzymskokatolickiego.

33 To jest w katedrze wileńskiej.

34 Sprawą kanonizacji królewicza Kazimierza zajmował się również Erazm Ciołek podczas swojego ostatniego poselstwa do Stolicy Apostolskiej (1518-1522). Misja zbadania cudów, które miały dokonać się za sprawą zmarłego królewicza, została powierzona legatom papieskim wysłanym na Litwę w 1520. Zob. Acta Nuntiaturae Poloniae, t. 2, Zacharias Ferreri (1519-1521) et nuntii minores (1522-1523), red. H.D. Wojtyska CP, Roma 1992, s. 9-10; Acta Tomiciana, t. 5, s. 190, 197.

35 Fryderyk Jagiellończyk (1468-1503), królewicz polski i książę litewski, najmłodszy syn króla polskiego Kazimierza IV Jagiellończyka i Elżbiety Rakuszanki. W 1488 roku został wybrany na biskupa krakowskiego, we wrześniu 1493 roku został wyniesiony przez papieża Aleksandra VI do rangi kardynała-prezbitera tytułu św. Łucji in septem soliis, a w październiku został wybrany na arcybiskupa gnieźnieńskiego i prymasa Polski.

36 Kazimierz IV Jagiellończyk i Elżbieta Rakuszanka mieli trzynaścioro dzieci, w tym siedem córek, które wydano za książąt niemieckich: Jadwiga (1457-1502) została żoną księcia bawarskiego Jerzego Bogatego; Zofia (1464-1512) poślubiła 
wyniesienie [swego] potomstwa zapragnął oglądać i [cel] osiągnął. Po dokonaniu przez niego żywota, trzeci z kolei syn, Jan Olbracht, obecnie najjaśniejszy król Polski, górujący nad innymi dużym doświadczeniem, wstąpił pokojowo na stolicę ojcowską ${ }^{37}$. Wówczas też pierwsi dostojnicy Wielkiego Księstwa [Litewskiego] natychmiast Aleksandra, czwartego syna, jednogłośnie wybrali na panującego i ojca ojczyzny ${ }^{38}$. Ozdobiony wszelkimi cnotami, okazał się pożądanym [władcą] nie tylko dla swoich, ale i dla obcych, a teraz już i dla wszystkich, gdyż powszechnie uważa się, że jest podobny do dziada w nienaruszalności religii, do stryja w stałości w wierze i jej obronie oraz do ojca w łaskawości i wrodzonej życzliwości. W wielkości zaś ducha i w osobliwej ozdobie szczodrobliwości słusznie może się równać z Aleksandrem Macedońskim. Pominąwszy inne [kwestie] teraz wypełnię to, co bieg gwiazd ku chwale chrześcijańskiego imienia zapowiada.

Przeto, Ojcze Święty, znakomity ten książę dla należnego obowiązku oddania czci z gorącym i szczerym uczuciem uznaje Ciebie za jedynego wikariusza Jezusa Chrystusa i najwyższego kapłana całej religii chrześcijańskiej, którego zapewnia o niezłomnej wierności i należnym posłuszeństwie, a także na wieki je przysięga. I chociaż tego później, niż powinien był, dopełnił, to jednak odległość i niespokojne czasy zwłokę tłumaczą ${ }^{39}$. To samo czynią wszyscy duchow-

Fryderyka Hohenzollerna, margrabiego brandenburskiego na Ansbach i Bayreuth; Anna (1476-1503) wyszła za księcia pomorskiego Bogusława X; Barbara (14781534) poślubiła księcia saskiego Jerzego Brodatego; Elżbieta (1482-1517) została żoną księcia legnickiego, Fryderyka II; dwie jeszcze córki umarły we wczesnym dzieciństwie.

37 Jan I Olbracht (1459-1501), syn Kazimierza IV Jagiellończyka i Elżbiety Rakuszanki, od 1492 roku król polski, w latach 1491-1498 książę głogowski.

38 Aleksander Jagiellończyk (1461-1506), syn Kazimierza IV Jagiellończyka i Elżbiety Rakuszanki, od lipca 1492 roku wielki książę litewski. W 1501 roku, po śmierci brata, Jana Olbrachta, został wybrany na króla Polski.

39 Ponowne nawiązanie do pozostawionego bez odpowiedzi listu papieża Aleksandra VI z 1498 roku, którym wzywał on wielkiego księcia litewskiego do przesłania poselstwa, by omówić kwestie związane z wspólną wyprawą przeciw Turkom. 
ni i świeccy prałaci Litwy, oraz całe to jakże ludne państwo. Oni wszyscy jednogłośnie wszędzie wyznają, że jesteś prawdziwym i prawomocnym następcą Piotra i jegoż łasce siebie pokornie polecają. Lecz żeby się nie wydawało, iż długą przemową raczej nużę pobożne uszy, niż cieszę. A wiem, Ojcze Święty, że Twoja najwyższa mądrość to wszystko poznała dokładniej z doświadczenia, nauczycielki życia, jako że przez długi czas szczęśliwie sprawowałeś urząd kanclerza Stolicy Apostolskiej ${ }^{40}$, kiedy usilnie dbałeś o kwitnący ten dom Białego Orła ${ }^{41}$. Bądź zatem stały i spraw, abyś to, coś wówczas dla chwały tej znakomitej rodziny pozyskiwał, dziś dawną życzliwością z pełni władzy [dzierżąc ster] na łodzi okazał i z własnej woli szerzył, wszystko bowiem możesz ${ }^{42}$. Rzekłem.

Na to papież zechciał udzielić dość obszernej odpowiedzi, chwaląc i wynosząc nadzwyczaj dziada, stryja i nie mniej ojca, oraz cały prawie ród najwyższego księcia. Wychwalał także jego własną cnotę, ogłosił publicznie, że obszerne księstwo Litwy, a także słynne królestwa Węgier i Polski są prawdziwym przedmurzem całego chrześcijaństwa i zawsze potężną osłoną od muzułmanów. Powtarzając na koniec poszczególne zdania wygłoszonej mowy, dziękował nieskończenie książęcej wysokości w imieniu swoim oraz przewielebnych kardynałów za tak wielką cześć i miłość wobec Stolicy Apostolskiej. Oświadczył wreszcie, że jest gotowy na wszystko, co przyniosłoby

40 Papież Aleksander VI (1431-1503), właściwie Rodrigo de Borja y Borja, był siostrzeńcem papieża Kaliksta III, który w 1457 roku mianował go wicekanclerzem Kościoła rzymskiego. Od końca lat 80. pełnił również funkcję protektora Jagiellonów. Zob. The History of Polish Diplomacy X-XX c. (10th to 20th Century), ed. by G. Labuda, Warszawa 2005, s. 121.

${ }_{41}$ Biały Orzeł stał się herbem Jagiellonów, panujących zarówno w Polsce, jak i w Budzie czy na Litwie.

${ }_{42}$ Zob. Vergilius, Aeneas, VI 117, gdzie to samo zdanie w innym szyku: „potes namque omnia”. 
zaszczyt księciu i jego państwu. Posła zaś ze szczególnej łaski własnoręcznie tamże uhonorował godnością protonotariusza ${ }^{43}$.

\section{Bibliografia}

Acta Nuntiaturae Poloniae, t. 2: Zacharias Ferreri (1519-1521) et nuntii minores (1522-1523), red. H.D. Wojtyska CP, Roma 1992.

Acta Tomiciana, t. V, wyd. T. Działyński, Poznań 1855.

AGAD, LL3 (Archiwum Główne Akt Dawnych, Liber Legationum 3)

ASV, Misc. Arm. XXXII, t. 21 (Archivio Segreto Vaticano, Miscelanea, Armarium XXXII, t. 21)

Barberi F., Tipografi Romani del Cinquecento, Firenze 1983.

Birkenmajer L., Zapiski historyczne wśród starych almanachów Biblioteki Jagiellońskiej, „Kwartalnik Historyczny” 16 (1902).

Brzozowska A., Wizerunek Polski i Litwy w mowach politycznych biskupa płockiego Erazma Ciołka (1474-1522), „Studia Classica et Neolatina” 12 (2014), s. 81-96.

Burchardus J., Diarium sive rerum urbanarum commentarii (1483-1506), t. 3: 15001506, Paris 1885.

Ciołek E., [...] ad Alexandrum sextum pontificem maximum in prestita obedientia Romae habita oratio, [Roma: Ioannes Besicken, 1501].

Dizionario Biografico, http://www.treccani.it/enciclopedia/giuliano-cesarini_\%28 Dizionario-Biografico\%29/.

Długosz J., Annales seu Cronicae incliti Regni Poloniae, ks. 11, 1413-1430, ed. J. Wyrozumski et al., Warszawa 2000.

Długosz J., Annales seu Cronicae incliti Regni Poloniae, ks. 11-12, 1431-1444, ed. J. Wyrozumski et al., Warszawa 2001.

Folwarski H., Erazm Ciołek biskup i dyplomata, Warszawa 1935.

Forestus I.Ph., Supplementum Chronicarum, Venezia 1535.

Fournier G., Geographica orbis notitia, per litora maris, et ripas fluviorum, Frankfurt 1668.

Hartleb K., Działalność kulturalna biskupa-dyplomaty Erazma Ciołka, Lwów 1929.

Lausberg H., Retoryka literacka. Podstawy wiedzy o literaturze, tłum. A. Gorzkowski, Bydgoszcz 2002.

Łowmianski H., Polityka Jagiellonów, Poznań 1999.

43 J. Burchardus, Diarium sive rerum urbanarum..., s. 123. 
Miaskowski K., Z biblioteki seminarium duchownego w Poznaniu „Przegląd Kościelny" 3 (sierpień 1904).

Mowa Erazma Ciołka, Przełożonego Wileńskiego, Najjaśnieszego Księcia Aleksandra W.K. litewskiego sekretarza i posła do Aleksandra VI Papieża z oświadczeniem postuszeństwa wyprawionego, miana w Rzymie roku pańskiego 1501, we środę, dnia ostatniego marca z dołaczeniem odpowiedzi Jego Świętobliwości, „Czas. Dodatek miesięczny" 20 (1860), s. 176-185.

Novum lexicon geographicum [...], ed. Ph. Ferrarius [...], ed. Michael Antonius Baudrand, t. I, Venezia: Homobono Bettanino, 1738.

Papée F., Aleksander Jagiellończyk, Kraków 2006.

Piccolomini A.S., De viris illustribus, Stuttgart 1842.

Pius II P.M., Asiae Europaeque descriptio, Köln 1531.

Podhorodecki L., Chanat krymski i jego stosunki z Polska w XV-XVIII w., Warszawa 1987.

Pułaski K., Stosunki z Mendli-Girejem, chanem Tatarów Perekopskich (1469-1515), w: Stosunki Polski z Tatarszczyzną od połowy XV wieku, t. 1, Kraków-Warszawa 1881.

Sanuto M., I Diarii, t. 3, Venezia 1880.

Schedel H., Liber Chronicarum cum figuris et imaginibus, Nürnberg 1493.

Skarbiec diplomatów papiezkich, cesarskich, królewskich, książęcych: uchwał narodowych, postanowień różnych władz i urzędów postugujących do krytycznego wyjaśnienia dziejów Litwy, Rusi litewskiéj i ościennych im krajów, zebrał i w treści opisał I. Daniłowicz, t. 1, wyd. J. Sidorowicz, Wilno 1860.

Statuta nec non liber promotionum philosophorum ordinis in Universitate Studiorum Jagiellonica ab anno 1402 ad annum 1849, ed. J. Muczkowski, Kraków 1849.

The History of Polish Diplomacy X-XX c. (10th to 20th Century), ed. G. Labuda, Warszawa 2005.

Theiner A., Vetera monumenta Poloniae et Lithuaniae [...], t. 2, Roma 1861. 